\title{
NIH cDNA patent rejected; backers want to amend law
}

\begin{abstract}
Washington. The US Patent Office has rejected a controversial application by the National Institutes of Health (NIH) for patents on more than 2,000 cDNA sequences. Although NIH is expected to appeal against the decision, the interim ruling could set a precedent that would ban patents on genes that share even tiny sections with already published sequences.
\end{abstract}

The ruling on 20 August finds the NIH sequences unpatentable on the grounds that they are 'obvious': many of the sequences contain small fragments that the patent office was able to find in other, already published, sequences. Once part of a sequence has been published, according to the patent office, it is a trivial matter to get a larger sequence or the entire gene.

Both NIH and Congress are expected to attack that decision on the grounds that, if allowed to stand, it would make impossible a patent for any gene containing sequences already patented. The NIH application, for example, covers fragments of human genes, several hundred bases long, whose function is unknown (see Nature 353, 485; 1991). Even if the patent office were eventually to grant that application, last month's ruling would deny a patent to those who had sequenced the full genes and found their function. That would effectively discourage many biotechnology companies from trying to find base products on those genes.

The patent office also ruled that the claimed sequences lack legal novelty because they were derived from publicly available cDNA libraries. In congressional testimony early this week, Bernadine Healy, the NIH director, also challenged that interpretation. "Taken to its logical extension, [the patent office reasoning] would deny novelty to other products isolated from expected sources of biomolecules, such as blood saliva or tissues", she argued.

At the same hearing, former NIH geneticist Craig Venter proposed a legislative solution to the dilemma posed by the patent office decision. Venter, who discovered the sequences last year but has since left $\mathrm{NIH}$ to start a new private research institute to pursue cDNA sequencing, suggests amending US patent laws to allow patents on sequences containing previously patented or published fragments. Senator Pete Domenici (Republican, New Mexico) intends to introduce the measure early next year.

Venter says that his change would not affect the status of his NIH application but would apply to subsequent filings. Changes to the patent code are not retroactive.
NIH officials say they were particularly disappointed with the ruling because it contains little discussion of the merits of gene patents and takes instead an extreme view on what might be called the inventiveness of the discoveries. If, the patent office argued, the cDNA sequences (which represent fragments of expressed genes of unknown function) contain base sequences that have already been published, then they fail the obviousness test; small fragments of the published sequences (from any species) could be used as a probe to search human DNA for a match.

NIH is partly to blame for this conclusion. In its application, NIH defines the sequences as both the full $400-500$ bases its researchers found for each gene and any $15-$ base fragment - known as a $15 \mathrm{mer}$ - of the larger sequences. Fifteen has traditionally been regarded as the minimum number of bases required to probe for a unique gene in unknown genetic material.

Using that yardstick, the patent examiners selected 15 mers at random from some 20 sequences in the NIH application and searched through databases of published sequences. After comparing the 15 mers with $300-400$ random sequences, they found a number of matches, including one to a mouse gene. That, they concluded, was enough to undermine NIH's case. "It would be obvious for one ordinarily skilled in the art" to take one of the published 15 mers and use it to probe for the NIH sequence in which it appears, the patent office concluded in its 30 -page interim ruling.

NIH's mistake was not in trying to pass off already published mouse genes as human brain cDNA but rather in assuming that a 15 mer would uniquely identify a gene. Despite the convention that 15 bases are enough for a unique probe, most researchers now believe that 30 , or even 50 , bases may be necessary to avoid the sort of spurious matches found by the patent office.

$\mathrm{NIH}$ has at least three months to file a revised application with the patent office. Although officials at its parent agency, the Department of Health and Human Services, would like NIH to withdraw its application and end the controversy, NIH patent officials are optimistic that their arguments will eventually carry the day. If the patent is indeed granted, Healy promised that NIH would not enforce its rights to any partial sequences of unknown function. Complete genes whose function has been determined are a different matter, she said, but NIH has not yet decided at what point to set that threshold.

Christopher Anderson

\section{Emphasis on research blamed for problems at US universities}

Washington. A new congressional report that blames the declining quality of public undergraduate education and soaring tuition fees on a preoccupation with research is viewed by university administrators and faculty as an uninformed attack on the role of research in education.

The report into the rising cost of a college education, prepared by the Select Committee on Children, Youth and Families of the US House of Representatives and released last week, accuses four-year state universities of emphasizing research for self-aggrandisement at the expense of undergraduate education. When professors spend too much time in the laboratory, according to the report, the results are large classes and a reliance on teaching assistants. The report contains data from a survey showing that, although faculty members teach for fewer hours than they did 30 years ago, few spend this extra time doing research.

The belief that 'quality' education is synonymous with high-powered research has also contributed to higher tuition fees, according to the report. Universities must hire more professors or teaching assistants to fill the gap left by faculty working at the bench, and their failure to serve as student advisers and carry out "other duties traditionally associated with the teaching profession" has forced universities to hire additional staff.

Although the report addresses some critical issues, such as the increasing use of teaching assistants, university officials say that its statistics are misleading and its conclusions naive. Statistics that lump together faculty members from disparate schools give an inaccurate picture of how professors spend their time, and recent sharp increases in tuition fees stem not from the neglect of teaching but from growing enrolments and insufficient funding from the state.

The report portrays research as an activity that public universities pursue to gain a cachet as elite institutions. But students who cannot afford private schools can gain research experience only at public universities, and research opportunities also help to attract the best faculty members.

University administrators are also unhappy that, at the congressional hearing on 14 September coinciding with the release of the report, the sole witnesses were two former academic officials and two students from large state universities whose statements echoed the arguments in the report. A congressional staff member who worked on the report explained the imbalance by saying that the academic community has had plenty of chances to testify "and the other side has not".

Traci Watson 